\title{
A VARIATION IN THE CHROMOSOME NUMBER OF THE ENGLISH RACE OF ANTHOCHARIS CARDAMINES L. (LEPIDOPTERA: $v$ PIERIDAE)
}

\author{
T. R. L. BIGGER \\ M.R.C. Radiobiology Unit, Harwell, Didcot, Oxon OX11 ORD
}

Received 7.xii.77

\begin{abstract}
SUMMARY
Studies of several populations of the English race britannica of Anthocharis cardamines show quite clearly that it has a chromosome number of $n=30$ differing from all other continental and Middle East races of the butterfly so far studied which are all $n=31$. A fusion of two chromosomes would appear to be the most likely explanation. Phenotypic differences between races are very slight. Evolutionary rates giving rise to both genotypic and/or phenotypic variations can be more rapid than had hitherto been thought likely, especially where populations become isolated. It would seem therefore that the lower chromosome number was evolved after the separation of the continent and southern England around 7000 years ago.
\end{abstract}

\section{INTRODUGTION}

Chromosome numbers have been determined for only a small proportion of the world's butterflies (Rhopalocera). The list of these numbers (Robinson, 1971) indicates that in the majority of cases where more than one population of a particular species has been examined the chromosome numbers from different localities show no variation. This includes some species where individuals may possess a variable number of B-chromosomes (Papilio machaon L., Pieris rapae L., P. napi L., Carcharadus flocciferus Zeller) but the basic chromosome number remains stable.

Stability is to be expected in species with known, regular migratory habits such as Pieris brassicae L., P. rapae L., and Aglais urticae L., but it is also found in many of the colonial species like Clossiana selene Denis and Schiffermüller, Cupido minimus Fuessly, and Plebejus argus L.

Recent research has, however, demonstrated that a few species, all of which are non-migratory, do exhibit a range of chromosome numbers. For example Lysandra coridon Poda has a range of numbers from $n=87$ in some Spanish populations to $n=92$ in races in the Balkans in a broad arc across western, central and southern Europe (de Lesse, 1969). Agrodiaetus dolus Huebner in Italy has a lower number $(n=122)$ than French populations $(n=124)$ (de Lesse, 1962, 1966), and the Nearctic Lycaenid Philotes sonorensis Felder and Felder has scattered colonies in California showing a wide range from $n=17.44$ (Emmel et al., 1973).

This paper reports a variation for the Pierid butterfly Anthocharis cardamines L., the Orange Tip. Specimens from several English populations are all $n=30$ in contrast to $n=31$ for all the European and Middle East populations so far investigated. 


\section{Materials and methods}

Testis and ovary tissue from adult butterflies of $A$. cardamines from Wantage, Oxfordshire, were treated in the same way as previously described in work on other Lepidoptera (Bigger, 1975) and good air-dried preparations were obtained. When the chromosome number variation became apparent, further populations from the southern half of England were sampled. In these cases the treatment involved only testis material and varied slightly from before. Male butterflies were injected in the abdomen with $0.1 \mathrm{ml}$ of $150 \mu \mathrm{g} / \mathrm{ml}$ solution of colcemid in saline to accumulate metaphases 3 hours prior to fixation. The testes were removed and immediately placed into fixative, fresh methanol/acetic acid $(3: 1)$ and stored below $0^{\circ} \mathrm{G}$ for from 1-7 days. They were then macerated in fresh $3: 1$ in small centrifuge tubes, centrifuged at 2000 r.p.m. for 2 minutes, given two further changes of fixative and the resultant cell suspension dispensed on to clean, greasefree, dry slides. The slides were stained in 2 per cent Giemsa buffered to $p \mathrm{H} 6.8$ for up to 30 minutes. Imagines were kept for phenotypic examination.

The preparations were examined and as many complete metaphases (both meiotic and mitotic) as possible were scored for each individual specimen.

\section{Results}

Fig. 1 shows the locations of the populations sampled, ranging from the far west in Cornwall to a point near Folkestone, Kent, only $45 \mathrm{~km}$ from the French coast, and as far north as Atherstone in Warwickshire.

The table gives details of the locations, numbers of specimens examined and numbers of cells scored. With one exception all the specimens showed

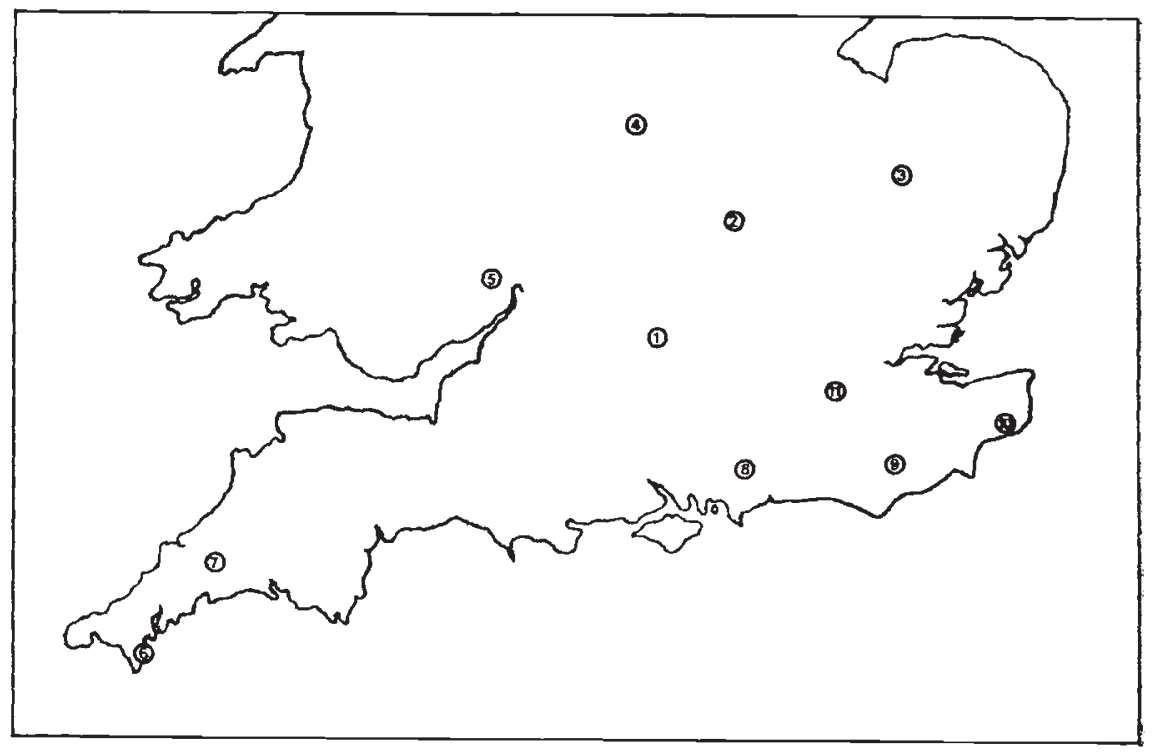

FIG. 1.-Locations of the 11 populations of Anthocharis cardamines sampled. 


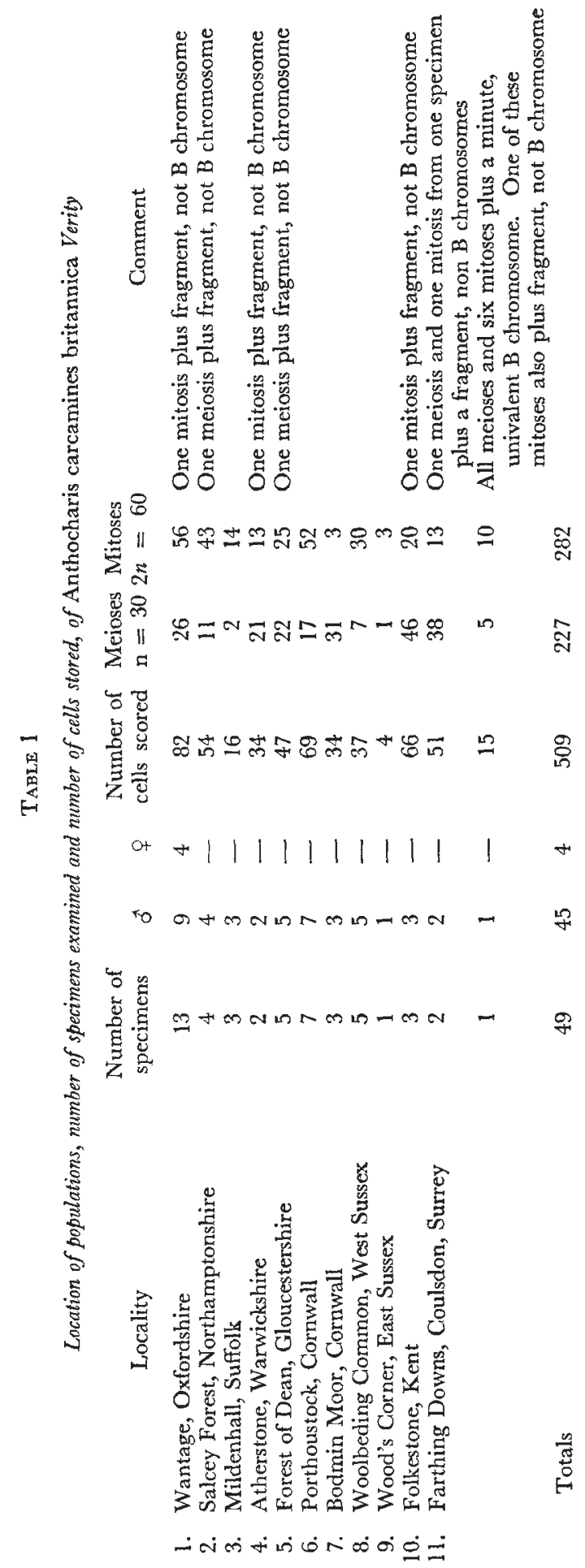

$41 / 1-E$ 
a haploid chromosome number of $n=30$. A normal meiotic metaphse (fig. 2) and a $2 n=60$ mitosis (fig. 3) are shown in the plate.

The exception, which again had the basic $n=30$ complement, also had a very small, extra univalent chromosome present in all meiotic cells and one-half of the mitoses scored. At mieosis it was never associated with any of the bivalents and was usually more faintly stained (fig. 4). In all probability this is a $\mathrm{B}$ chromosome.

Similar supernumerary or B chromosomes have previously been found in some other species of the Pieridae (Maeki and Remington, 1960; Lorkovic, 1968; Bigger, 1976).

In the specimens without the B chromosome, seven of the 494 cells scored were found to possess an extra fragment. These fragments varied in size and were as intensely stained as the other chromosomes. Such fragments have been found with a frequency of less than 2 per cent in Pieris rapae and $P$. napi (Bigger, unpublished).

A small proportion of the meiotic cells showed asynapsis of one of the bivalents, usually one of the smallest pairs (fig. 5).

\section{Discussion}

Up to the present time about 700 species of the world's Rhopalocera have had their chromosome numbers determined. Most of these are tabulated by Robinson (1971) and a study of his lists shows that the chromosome numbers of only about 120 of these species have been established by different workers from two or more populations or races of them. Of these, 40 species show a variable chromosome number. Part at least of this variation is probably due to the inadequate cytological procedures used in the past, and the fact that often only one specimen and/or a few dells were examined. Moreover, current work with British butterflies indicates that supernumerary B chromosomes occur fairly frequently (six out of 25 British species studied so far have them), and since their number can vary both between and within individuals as well as between populations (Lorkovic, 1968; Bigger, 1976), this factor may also have contributed to the recorded variation. Modern cytological methods usually allow $\mathrm{B}$ chromosomes to be distinguished by their fainter staining and their smaller size, although exceptions exist, e.g. Pieris rapae (Bigger, 1976).

A third factor which will contribute when counts are confined exclusively to meiotic material is the asynapsis involving usually one of the smaller bivalents that sometimes occurs in a small proportion of cells. In $A$. cardamines six specimens from the 21 scored with meiotic cells had asynaptic bivalents in 15 out of 227 meioses.

A fourth factor is gross chromosome fragmentation or fusion which is sometimes found in a few species leading to large variations between individuals from one population, e.g. Leptidea sinapsis (Federley, 1938; Lorkovic, 1941), Philotes sonorensis (Emmel et al., 1973). Also spontaneous chromosome fragments are found in a minority of normal meioses and mitoses. They can be distinguished from B chromosomes by their variation in size and their staining intensity which is the same as the normal chromosomes. The table shows that less than 2 per cent of the cells scored for $A$. cardamines possessed a chromosome fragment (eight cells from 509).

It therefore seems essential that several specimens from each of two or 
more populations should be examined in order to eliminate these factors when establishing any numerical variation in the basic chromosome complement. Relatively few published cases meet this requirement. Examples are Lysandra coridon, $n=87-92$ (de Lesse, 1969), Agrodiaetus dolus, $n=122$ 124 (de Lesse, 1962, 1966), and Philotes sonorensis, $n=17-44$ (Emmel et al., 1973).

To this list Anthocharis cardamines can now be added. The English race clearly has one less chromosome pair than the continental and Middleeastern races examined by other workers.

$A$. cardamines ranges from western Europe and the Middle East across temperate Asia to China (Higgins and Riley, 1970). It inhabits flowery meadows, woodland borders and downland with a preference for areas where there is plenty of light woodland and coppice where the principle foodplants grow (Cruciferae: Cardamine, Sysimbrium, etc.) and this appears to be the only restriction to its range (Dennis, 1977). The species seems to disperse along the lines of hedgerows, roadsides, streams and canals, but it is not known to have a migratory habit so it would certainly be unable to. cross the sea.

All the races so far studied show the chromosome number to be $n=31$, i.e. the Lebanese race phoenissa von Kalchberg (Larsen, 1975), race turritus Ochsenheimer from both the French Maritime Alps and from near Zagreb, Jugoslavia (Lorkovic, 1941), and the nominate race from Finland (Federley, 1938) and from a locality only $130 \mathrm{~km}$ from the English Channel at St Germain, Seine et Oise (de Lesse, 1960). The English race britannica Verity was sampled before (Bigger, 1960) and found to be $n=30$ but because of the poor method of slide preparation then in use the counts were presumed to be incorrect or that the individual studied was aberrant. It. was not until this current population study was started that it was confirmed as $n=30$.

A close study of the illustrations of $A$. cardamines meioses in earlier papers (Federley, 1938; Lorkovic, 1941) clearly show cells with 31 bivalents. In the former work an oogonial meiosis showed 32 elements. Two of these are very small and identical to one another, and would appear to be an asynaptic bivalent, the other 30 elements are clearly bivalents. All the female specimens studied from the English race were $n=30$. As mentioned previously asynaptic bivalents are often found in the male's meioses, some of the earlier stages of which can be seen to have bivalents with clear chiasmata. Female meioses which are less often found in ovarian preparations have, without exception in the species studied so far, bivalents which are achiasmatic (Suomalainen et al., 1973; Bigger, 1975; Fontana, 1976).

Four other species of the Anthocharidi have had their chromosome numbers determined and three of them are $n=31$. A. scolymus Butler (Maeki, 1953), A. damone Boisduval (Larsen, 1975), and A. euphenoides Staudinger (de Lesse, 1970) are $n=31$ whilst $A$. gruneri Herrich-Schaeffer (in Robinson, 1971) is the exception with $n=24$. It seems therefore that $n=31$ is the modal number for this genus.

Although the English race has been named britannica there appears to. be only a slight phenotypic difference between it and the nominate race occupying western France which is $n=31$ (de Lesse, 1960), namely a tendency for the orange area of the male's forewings to be slightly smaller in britannica, and the forewing apical black crescent and the hindwing: 
marginal black spots at the end of each vein more conspicuous. However, there is some overlap of these characters between the races (Dennis, 1977). It would appear then that since there is so little phenotypic difference it is most likely that the English race's chromosome complement has been changed by the fusion of two chromosomes rather than the complete loss of one. A comparison of the G-banded mitotic chromosomes from both races would have to be done to show this conclusively.

Another example of a species of butterfly now known to vary genotypically from the nearest continental race without gross phenotypic variation is Lasiommata megera $\mathrm{L}$. Thisiis shown to differ genotypically by crossbreeding experiments between English and French populations which result in reduced egg fertility and reduced viability of backcrosses (Oliver, 1972). This evidence together with the results of population studies on the variation of underwing spotting in Maniola jurtina L. (Dowdeswell and McWhirter, 1967; McWhirter, 1969) where spotting frequencies of colonies in west Cornwall and the Scilly Isles differ from those of other English mainland populations, indicates that the evolutionary rates of both genotypic and phenotypic variation can take place much faster than had previously been thought possible. This is due to the isolation of the various populations and would lead to a more rapid emergence of racial diversity.

It is now evident from recent research into the origins of the butterflies of the British Isles (Dennis, 1977) that none survived the severe glaciation prior to 17,000 years B.P. (before present). With improving climate and vegetation changes leading to the gradual movement of butterflies from the south of Europe, A. cardamines probably re-entered England around 10,000 B.P. across the continental land bridge, subsequently spreading rapidly to Ireland and the Isle of Man before the land connections with the English mainland were severed (to Ireland at about 9500 B.P. and the Isle of Man 9200). The mainland populations would have continued to be reinforced by dispersal from the continent until that too was separated by the hiatus in 7500-7000 B.P.

It is apparent that British butterfly populations have not evolved to separate species in 9500 years, but a minority of distinct races have been produced, as is now demonstrated in the case of $A$. cardamines with its different chromosome number.

At the moment no definite conclusion as to when the English race evolved its lower chromosome number can be made, but due to the very widespread range of $n=31$ populations on the continent and the isolated nature of the English race, it is likely that it took place after the separation of England and France. In this connection a determination of the chromosome number of the Irish race hibernica Williams would be of considerable interest. The phenotypic character differences which exist between britannica and the continental races tend to be accentuated in hibernica, although once again there is considerable overlap.

It would also be of interest now to examine other non-migratory colonial species, especially those with no obvious phenotypic differences from European forms, to see whether similar numerical or structural chromosome differences exist.

Acknowledgment.-I would like to thank Dr J. Vennart, Director of the Radiobiology Unit, for his kind permission to use the facilities of the laboratory for the completion of this work. 


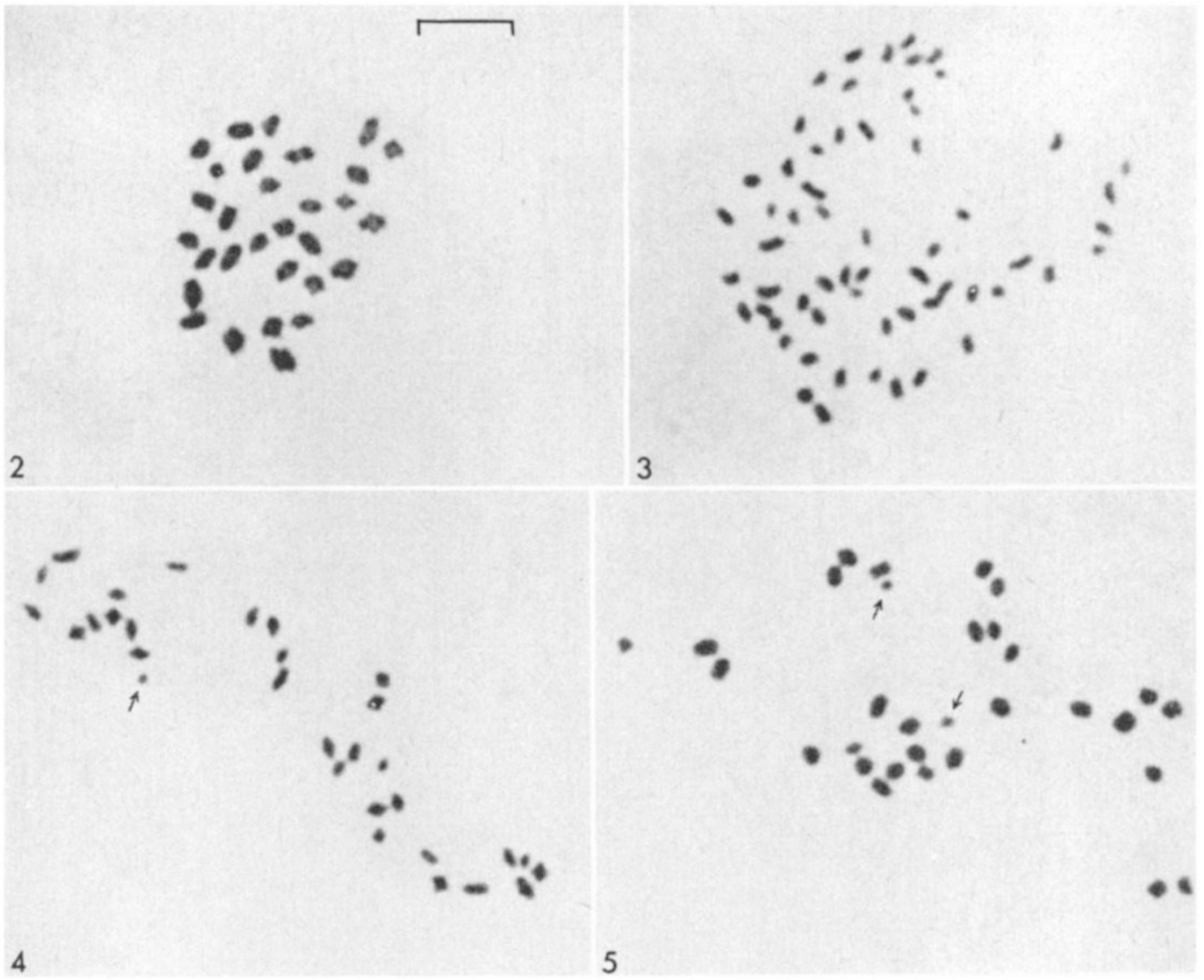

Figs 2-5.-Anthocharis cardamines male meiotic and mitotic chromosome preparations. Fig. 2: Normal meiosis $n=30$. Fig. 3: Normal mitosis $2 n=60$. Fig. 4: Meiosis with supernumerary B chromosome (arrow). Fig. 5: Meiosis with one asynaptic bivalent (arrows). (Bar $=5 \mu)$. 


\section{REFERENGES}

BIGGER, T. R. L. 1960. Chromosome numbers of Lepidoptera. I. Entomologist's Gaz., 11, 149-152.

BIGGER, T. R. L. 1975. Karyotypes of some Lepidoptera chromosomes and changes in their holokinetic organisation as revealed by new cytological techniques. Cytologia, 40 , 713-716.

BIGGER, T. R. L. 1976. Karyotypes of three species of Lepidoptera including an investigation of B-chromosomes in Pieris. Cytologia, 41, 261-282.

DENNIS, R. L. H. 1977. The British Butterflies their Origin and Establishment. Classey, Faringdon, Oxford.

DOWDESWELl, w. H., AND MCWHIRTER, k. 1967. Stability of spot distribution in Maniola jurtina throughout its range. Heredity, 22, 187-210.

EMmel, T. C., TREW, H. R., AND SHIELDS, o. 1973. Chromosomal variability in a Nearctic Lycaenid butterfly Philotes sonorensis Felder and Felder. Pan-Pacific Ent., 49, 74-80.

FEDERLEY, H. 1938. Chromosomenzahlen finnlandischer Lepidopteren. I. Rhopalocera. Hereditas, 24, 397-464.

FonTANA, P. G. 1976. Improved resolution of the meiotic chromosomes in both sexes of Euxoa species and their hybrids (Lepidoptera: Noctuidae). Can. 7. Genet. Cytol., $18,537-544$.

HIGGins, L. G., AND RILEY, N. D. 1970. A Field Guide to the Butterfies of Britain and Europe. Collins, London.

LARSEN, T. B. 1975. Chromosome numbers and notes on testicular morphology of some Lebandse Rhopalocera (Insecta: Lepidoptera). Ent. scand., 6, 253-260.

LESSE, H. DE. 1960. Spéciation et variation chromosomique chez les Lépidoptères Rhopalocères. Ann. Sc. Nat. Zool., $12^{\mathbf{e}}$ series, 1-223.

LESSE, H. DE. 1962. Variation chromosomique chez Agrodiaetus dolus Hbn. (Lep. Lycaenidae). Alexanor, $I I, 283-286$.

LESSE, H. DE. 1966. Variation chromosomique chez Agrodiaetus dolus Hbn. (Lep. Lycaenidae). Ann. Soc. ent. France, 2, 209-214.

LESSE, H. DE. 1969. Les nombres de chromosomes dans le groupe de Lysandra coridon (Lep. Lycaenidae). Ann. Soc. ent. France, 5, 469-522.

LESSE, H. DE. 1970. Formules chromosomiques de quelques Rhopalocères paléarctiques. Bull. Soc. ent. France, 75, 214-216.

LoRkovic, z. 1941. Die Chromosomenzahlen in der Spermatogenese der Tagfalter. Chromosoma, 2, 155-191.

LORKovic, z. 1968. Systematisch-genetische und ökologische Besonderheiten von Pieris ergane Hbn. (Lep. Pieridae). Mitt. Schweizn. Ent. Ges., 41, 233-244.

MAEkI, K. 1953. Chromosome numbers of some butterflies (Lepidoptera: Rhopalocera). Jap. journ. genetics, 28, 6-7.

MAEKI, K., AND REMington, C. L. 1960. Studies of the chromosomes of North American Rhopalocera. 2: Hesperiidae, Megathymidae, Pieridae. Journ. Lepid. Soc., 14, 37-57. MCWHIRTER, K. 1969. Heritability of spot-numbers in Scillonian strains of the Meadow Brown butterfly (Maniola jurtina). Heredity, 24, 314-318.

oliver, c. c. 1972. Genetic differentiation between English and French populations of the Satyrid butterfly Pararge megera L. Heredity, 29, 307-313.

Robinson, R. 1971. Lepidoptera Genetics. Pergamon Press. Oxford.

SUOMALAinen, E., COOK, L. M., AND TURnER, J. R. G. 1973. Achiasmatic oogenesis in the Heliconiine butterflies. Hereditas, 74, 302-304. 